\title{
Irony as an Agent of Precision in the Poems of Nissim Ezekiel
}

\section{Dr. Sumanjari.S}

Asst Professor, Dept of English \& Cultural Studies, CHRIST (Deemed to be University), Bangalore, India

Received: 28 Sep 2021; Received in revised form: 29 Oct 2021; Accepted: 07 Nov 2021; Available online: 13 Nov 2021

(C)2021 The Author(s). Published by Infogain Publication. This is an open access article under the CC BY license

(https://creativecommons.org/licenses/by/4.0/).

\begin{abstract}
Nissim Ezekiel is known for irony in his writings. His poems are filled with verbal irony, irony of characters, irony of situations, irony of life and subtle irony. His technique in writing is unique and attracts a large number of readers. This article studies few of Ezekiel's poems which uses irony as an important element in writing. It attempts to study irony as an agent of precision in his poems. The use of sarcasm and subtle humour are brought forward in his writings which is illustrated in this article. Experiences, situations, human values and happiness are few of such factors are studied through his poems where irony and satire act as strong agents. The harmony of emotional effects and Ezekiel's sensibility are also studied and documented in the article. The article explores the creative use of irony through Ezekiel's poems.
\end{abstract}

Keywords-Agent, Humour, Irony, Precision, Sarcasm, Satire.

Nissim Ezekiel uses irony as an agent of precision. His intention is to present "exactness" and even the minute accuracy. He conveys meaning by words whose literal meaning is the opposite. Irony, in his poems is generally satirical. He mostly presents to the readers a condition in which one seems to be mocked by fate or facts. The irony has a significance unperceived at the same time or by the person involved. He teaches us that life is a journey for wholeness, intellectual and spiritual happiness, and maturity through the sarcasm in his poems (Hasan, 2008). While the goal is to free the spirit from distractions and obsessions, it is based on physical and social realities. The quest is primarily about how to live as an integrated human being in a happy, tranquil, and ethical manner (King, 2005).

In his poem "Theological"Ezekiel says about the use of irony in his poems as,
"I am tired
of irony and paradox
of the bird in the hand
and the two in the bush
of poetry direct and oblique

of statement plain and symbolic..." (157)

Ezekiel is claimed to have perfected subtlety with "The Exact Name." This is largely due to his ability to obtain more useful precisions of insight through the employment of various types of irony. His irony, however, did not turn into a scathing scepticism. It is possible to analyse his usage of irony in certain of his poetry. It's worth noting that his irony serves a specific function in each of his poetry.

The irony in "Night of the Scorpion" can be detected in the poem's structure. In terms of sarcastic contrast, the second stanza is related to the first. The neighbours discuss the crimes of his mother's past births, the tragedies of her future birth, and the sum of good and evil in the first stanza, which only added to the mother's anguish from being stung by a scorpion. The father, a sceptic and rationalist, tries numerous tactics to make the poison lose its sting in the second verse and eventually succeeds. These are some of the first stanza's lines.

\section{"May the sins of your previous birth \\ be burned away tonight, they said}

May your suffering decrease 
The misfortunes of your next birth, they said."

In contrast to the first stanza here are some of the lines from the second stanza.

"My father, sceptic, rationalist,

tried every curse and blessing, ...

I watched the holy man perform his rites

To tame the poison with an incantation." (36)

When the poet claims that the peasants sat about on the floor with the narrator's mother in the centre with "peace of understanding on each face" when the mother was in pain, it's ironic (Paul,1999). Instead of healing her, they just spoke about high philosophy. After a day, the poison has worn off, and, in a last irony, his mother, in contrast to the prior frenetic activity focused on her, makes a normal motherly remark.

\section{"Thank God the scorpion picked on me} and spared my children" (46)

The term "Thank God" is ironic because it is a response to all of the prior religious and superstitious action. Ironically, the revelation of a need for God is frequently articulated.

"Background, Casually" is a long poem divided into three sections. The storey is chock-full of deflatory irony. The poem's value stems from the fact that it attempts to elucidate some of the background of human experience and attitude from which the irony emerges. In the first sentence, "A poet-rascal-clown was born," there is a scornful and cynical tone.In a confessional tone, he writes the poem.Although he did win the scripture prize when he was in school, he was seen as "a mugging Jew among the wolves" (7)

\section{"They told me I had killed the Christ,}

that year I won the scripture prize". (8-9)

His poetry has served as a mirror, portraying life in this "backward area" as it is lived (Patel,2008).In his poetry, he expresses his sardonic approach toward life and religion. He acknowledges that the more he looked, the less he found. With him, a post-colonial poetry emerged, reflecting the lives and identities of an expanding number of educated Indians.

A description of a monkey show on each street corner in India is provided in "Entertainment." Ezekiel illustrates not just the situation of the unfortunate monkeys, but also the funny reactions of diverse segments of the crowd. Some men watch the show but do not pay for it, which is humorous and typical of the Indian atmosphere.

"Anticipating time for payment,

\section{the crowd dissolves \\ some, in shame, part}

with the smallest coin they have,

the show moves on." (26)

The poem "The Truth about the Floods" has an unusual subject, but the treatment is universal in its portrayal of human pain. Ezekiel establishes the atmosphere of the flood-affected areas in the first few lines. An authentic atmosphere is created through images of "paddy-fields with knee-deep water" and how "all the houses had collapsed". The government officials, on the other hand, are apathetic and uninterested. Nature gets blamed for everything. This poem is full with bitter irony and poignancy. Because they misunderstood the reporter for a government official, the locals refused to speak with him. There is a lot of mistrust and suspicion. Ironically, the relief efforts are led by students who arrive with transistors and Hindi movie soundtracks.

"The district authorities

at Balasore

admitted they had failed,

but they claimed they could not have done better

Nature, they said,

had conspired against them". (32)

"In India" exemplifies the irony in action. In the form of satire, there is a brutal sarcasm on the low position of women in India. They are viewed as second-class citizens, while men influenced by Western culture are free to behave as they like. This unequal treatment of men and women is exemplified in the following lines:

"The wives of India sit apart.

They do not drink,

they do not talk,

of course, they do not kiss.

The men are quite at home

among the foreign styles

(what fun the flirting is!)

I, myself, decorously,

press a thigh or two in a sly innocence.

The party is a great success.

For males, flirtation is a luxury, but for women, it is not. The clash of civilizations is ironically depicted in the last act, when the English boss tries to seduce his Indian secretary and discovers a blouse to be a joyful hunting ground by Indian morality standards. 
"Certainly the blouse

would not be used again.

But with true British courtesy

he lent her a safety pin

before she took the elevator down." (64)

These phrases demonstrate a flair for both provocative and sardonic vision. The woman believes that the Englishman will provide her with all of the benefits of Western civilization. She is subjected to his obnoxious lust, which he tries to impose on her.

Irony plays a vital role in his poem "Theological," placing experience and sharpening discriminations.

\section{"You are truth}

is too momentous for man

and not always useful". (12)

The lines emphasise the legitimacy of the "normal" despite the contrast's intensity, and the instrument used is irony. "Poem of the Separation" expresses the same sentiment.

"Any man may be a whirlwind

any woman lightning

but buses take us to our meeting

trains to our destination" (7)

In "The Double Horror," he conveys his concerns. In this poem, he denounces the reality that in this world of mass civilisation, minority culture has no place in "newspapers, movies, radio features, speeches." He tries to incorporate his satirical tone into the urban setting:

bottles,

"Posters selling health and happiness in

large returns for small investments, in football pools

or self-control, six easy lessons for a pound,

holidays in Rome for writing praise of toothpastes," (5)

The irony in this poem alludes to the flimsy existence of city life. The city dweller gets an image for his mechanical movements and regular acts in the poem "Urban." $\mathrm{He}$ shows us the perilous comedy of city life (Shaila, 2001). These are poems written by a modern city dweller who is unaffiliated with any religion but requires some form of belief in order to feel at ease.

\section{"He knows the broken roads and moves}

in circles tracked within his head." (2)

Ezekiel confesses his apprehension of sex failure, which could lead to a frozen lack of commitment. In "The
Unfinished Man," where the irony resides between reality and illusion, he expresses his failure.

\section{"Remote from the exploring act}

I knew that both were undefined,

who lived in daydream, not in fact:

reflections of the cheated mind. (16)

Ezekiel's personal ideal of marriage was not realised, which is ironic. He declares,

"His marriage was the first mistake of all. came....

Although he loved his children when they

A man is damned in that domestic game." (23)

"Guru" contains yet another irony in the shape of sarcasm. Every man, according to Ezekiel, is prone to making mistakes. Even the saintliest person can be a rogue. The second stanza is unremarkable, but it highlights the flaws of a so-called sadhu. For their ostensibly spiritual activities, some phoney saints receive money and other gifts. They simply claim to be healers, which is untrue. Ezekiel is ironical in his satire on false yogis.

"But then we learn;

the saint is still a faithless friend"(11)

A deconstructive relationship to Sanskrit texts is suggested in "The Egoist's Prayers," which is drawn from "hymns in darkness." These aren't anthems to the unfathomable heavenly darkness. The "hymns" are in "darkness" for the poet.

In his poem "The Hill", he talks about man who must not rest in irony. He says,

\section{"Be wrathful, be impatient \\ that you are not \\ on the Hill. Do not forgive \\ yourself or others, \\ though Charity \\ is all very well \\ do not rest \\ in irony and acceptance.(43)}

Ezekiel's poetry, more than that of any other of these writers, appears to be formed from within and to have within it a natural capacity for development. It is cognitively challenging, language is fluid, diction is precise, and acceptance is austere. His more recent style, which is honest and deeply introspective, is a clear indication that Ezekiel is a poet whose creation is not separate from the stresses and priorities of daily 
life.Ezekiel uses creativity even in his irony (Taranath\&Belliappa, 1966).

\section{REFERENCES}

[1] Ezekiel Nissim. Interviews with Nissim Ezekiel. Journal of South Asian Literature, 1986.

[2] Karnani, Chetan (2001). Eminent Indian English Writers. Rawat Publications.

[3] King, Bruce (2005). Modern Indian Poetry in English. Oxford University Press.

[4] Mahan Shaila (2001). The Poetry of Nissim Ezekiel. Jaipur: Classic Publications.

[5] Noorul Hasan (2008) Nissim Ezekiel Remembered. ed. Havovi Anklesaria. New Delhi: Sahitya Akademi.

[6] Patel,Gieve (2008). A Recollection, Nissim Ezekiel Remembered. ed. Havovi Anklesaria. New Delhi: Sahitya Akademi.

[7] Paul SK (1999). Nissim Ezekiel's Indianness. Punjab Journal of English Studies. 14:101-107.

[8] Saleem Peeradina (1972) Contemperory Indian Poetry in English: An assessment and selection, Macmillan India.

[9] Taranath, Rajeev \&Bellaiappa, Meena (1966). The Poetry of Nissim Ezekiel, Calcutta.Writers Workshop, 1966). pp.8-9. 7. 